\title{
AORTIC VALVE REPLACEMENT WITH A PULMONARY AUTOGRAFT IN INFANTS WITH CRITICAL AORTIC STENOSIS
}

Göran Südow, MD

Laszlo Solymar, $\mathrm{MD}, \mathrm{PhD}$

Håkan Berggren, $\mathrm{MD}, \mathrm{PhD}$

Bengt Eriksson, MD, PhD

Daniel Holmgren, $\mathrm{MD}, \mathrm{PhD}$

Tomas Gilljam, MD

\begin{abstract}
Seven patients with critical aortic stenosis underwent aortic valve replacement with a pulmonary autograft (the Ross operation) between the ages of 5 weeks and 9 months. The operation was considered mandatory for survival because of continued severe heart failure or valve avulsion. Six of the patients had undergone unsuccessful previous palliations, such as commissurotomy, balloon dilation, and transventricular valvotomy, performed singly ( $n=1$ ) or in combination $(n=5)$. The other patient with a severely hypoplastic aortic valve ring underwent the Ross procedure as a primary operation. Two operative deaths occurred. In both cases severe endocardial fibroelastosis was detected at autopsy. One late death 1 year after the operation resulted from progressive hypertrophic cardiomyopathy and pulmonary hypertension. The rest of the patients are doing well, without medications. Apart from trivial regurgitation in two patients, the pulmonary autograft is performing well. ( $\mathrm{J}$ Thorac Cardiovasc Surg 1996; 112:433-6)
\end{abstract}

$\mathrm{C}$ ritical aortic stenosis in infancy is associated with high morbidity and mortality ${ }^{1-3}$ and necessitates urgent intervention for patient survival. If the size of the left ventricle is adequate for biventricular repair, aortic valve dilation or valvotomy will effectively reduce the left ventricular outflow tract (LVOT) stenosis in the majority of cases. ${ }^{4-7}$ However, some patients continue to have severe heart failure because of persistent LVOT obstruction or postoperative aortic regurgitation or because other complications related to the primary palliation operation develop, making further corrective procedures mandatory. Pulmonary autograft replacement, the Ross operation, ${ }^{8}$ has been used successfully in older children by us and others to replace diseased aortic valves. ${ }^{9-12}$ Inasmuch as further conservative procedures were unlikely to succeed in our infants, we used this technique as a salvage operation. This

From the Departments of Thoracic Surgery and Pediatrics I, Section of Pediatric Cardiology, University of Göteborg, Göteborg, Sweden.

Supported by a grant from The Göteborg Medical Society.

Received for publication Oct. 23, 1995; revisions requested Jan. 2, 1996; revisions received Feb. 5, 1996; accepted for publication Feb. 7, 1996.

Address for reprints: Laszlo Solymar, MD, Department of Pediatrics I, Section of Pediatric Cardiology, University of Göteborg, East Hospital, S-416 85 Göteborg, Sweden.

Copyright $(\mathcal{C} 1996$ by Mosby-Year Book, Inc.

$0022-5223 / 96 \$ 5.00+0 \quad \mathbf{1 2} / \mathbf{1} / \mathbf{7 2 5 6 1}$ report deals with our successes and failures using the Ross operation in this uncommon but challenging subgroup of patients.

\section{Patients and methods}

Patients. Six patients with critical aortic stenosis underwent primary palliation with transventricular dilation (Hegar dilator), open valvotomy, and balloon dilation as single operations $(n=3)$ or as repeated procedures in various combinations $(n=3)$. In one patient, first seen at the age of 5 weeks, valve replacement with a pulmonary autograft was the primary mode of treatment because of a narrow aortic valve ring. All but one were referred for treatment within the first days of life and were dependent on prostaglandin infusion for ductal patency and right ventricular assistance to maintain adequate systemic circulation. Despite these measures, four patients continued to have severe congestive heart failure, mainly because of significant residual stenosis, and needed continuous ( $n=$ 1) or repeated $(n=3)$ ventilatory support, as well as extensive treatment for heart failure. Their critical condition made aortic valve replacement mandatory. In two patients aortic valve evulsion was a complication of transventricular dilation with a Hegar dilator; this damage and the risk of aortic dissection were the major reasons for the aortic valve replacement.

Methods. The operation was performed through a median sternotomy. Conventional cardiopulmonary bypass with a membrane oxygenator and general hypothermia to $20^{\circ} \mathrm{C}$ was used. Both the aorta and the pulmonary artery were mobilized before bypass was begun. After the initiation of bypass, the aorta was crossclamped and cardioplegic solution was infused. The aorta was transected and the coronary arteries 
Table I. Associated anomalies, previous palliations, and clinical status of patients before the Ross procedure

\begin{tabular}{clcclc}
$\begin{array}{c}\text { Patient } \\
\text { No. }\end{array}$ & Associated anomalies & $\begin{array}{c}\text { EFE } \\
\text { by echo }\end{array}$ & $\begin{array}{c}\text { PGE } \\
\text { dependent }\end{array}$ & Primary palliation & $\begin{array}{c}\text { Age at primary } \\
\text { palliation (days) }\end{array}$ \\
\hline 1 & MR & Yes & Yes & Transventricular dilation & 1 \\
2 & COA, PDA, ASD & Yes & Yes & COA repair, transventricular dilation & 6 \\
3 & None & Yes & Yes & Transventricular dilation & 4 \\
4 & HNCM & No & Yes & Open valvotomy & 3 \\
5 & MR & No & Yes & Transventricular dilation & 2 \\
6 & None & No & Yes & Transventricular dilation & 2 \\
7 & PDA, MR & Yes & No & Ross operation & 35 \\
\hline
\end{tabular}

$\overline{E F E}$, Endocardial fibroelastosis; $e c h o$, echocardiography; $P G E_{F}$, prostaglandin $\mathrm{E}_{1} ; A o / P a$, aorta-pulmonary artery size difference; $M R$, mitral regurgitation; $C H F$, congestive heart failure; $C O A$, coarctation of the aorta; $P D A$, persistent ductus arteriosus; $A S D$, atrial septal defect; $A R$, aortic regurgitation; $N A$, not applicable; $H N C M$, hypertrophic nonobstructive cardiomyopathy.

Table II. Surgical results and follow-up data of the infants operated on with the Ross procedure

\begin{tabular}{|c|c|c|c|c|c|}
\hline $\begin{array}{c}\text { Patient } \\
\text { No. }\end{array}$ & Clinical status & Cause of death & $\begin{array}{c}\text { Follow-up } \\
\text { (mo) }\end{array}$ & Reoperations & $\begin{array}{c}\text { Age at } \\
\text { reop (mo) }\end{array}$ \\
\hline 1 & Alive, asymptomatic & $\mathrm{NA}$ & 45 & None & \\
\hline 2 & Alive, mild CHF & NA & 44 & None & \\
\hline 3 & Dead postop. & EFE (severe) & $\mathrm{NA}$ & NA & \\
\hline 4 & Dead late & HNCM, PHT & 11 & $\begin{array}{l}\text { 1. Repair of homograft } \\
\text { 2. Left pulmonectomy }\end{array}$ & $\begin{array}{r}9 \\
11\end{array}$ \\
\hline 5 & Alive, asymptomatic & NA & 34 & None & \\
\hline 6 & Alive, asymptomatic & $\mathrm{NA}$ & 31 & None & \\
\hline 7 & Dead postop. & EFE (severe) & $\mathrm{NA}$ & $\mathrm{NA}$ & \\
\hline
\end{tabular}

LVOT, Left ventricular outflow tract; anas., anastomosis, $L V$, left ventricular; $N A$, not applicable; $A R$, aortic regurgitation; $M R$, mitral regurgitation; $C H F$, congestive heart failure; $E F E$, endocardial fibroelastosis; $P H T$, pulmonary hypertension; $H N C M$, hypertrophic nonobstructive cardiomyopathy.

were mobilized and resected out of the aorta with a 2 to $3 \mathrm{~mm}$ rim of the aortic wall. The valve and part of the valve ring on the anterior side were excised. Because of the mismatch between the aorta and the pulmonary artery (Table I), a small part of the anterior muscle was resected to allow the LVOT to be widened. The suture line was reinforced with a pericardial strip in this region. Resection of the ventricular septum by the Morrow technique ${ }^{13}$ for further widening of the LVOT was used in our final five patients. The pulmonary root was excised by dividing the main pulmonary artery at the bifurcation and proximally by resecting the right ventricular outflow tract just below the arteriomuscular junction. The pulmonary autograft was trimmed of excessive muscle tissue, rotated into position, and sutured to the LVOT with continuous 5-0 Prolene suture (Ethicon, Inc., Somerville, N.J.). Two openings were created in the vessel wall to accommodate the coronary arteries, which were reanastomosed with a continuous 6-0 PDS suture (Ethicon). After this, we inserted the distal suture line in the connection between the pulmonary artery and an allograft (either aortic or preferably pulmonary) with a 6-0 Prolene suture. We then anastomosed the autograft to the ascending aorta and connected the allograft centrally to the right ventricular outflow tract. A moderate degree of oversizing was allowed for the allograft to postpone the problem of outgrowing the conduit. The length was adjusted carefully to avoid kinking or stretching. Rewarming was continued until the rectal temperature reached $36^{\circ} \mathrm{C}$. When the patient was weaned from bypass, hemoconcentration was performed until a normal hematocrit value was reached.

\section{Results}

Five patients (71\%) survived the operation. Of the two pat ients who died, one could not be weaned from bypass and the other died after 24 hours with the clinical picture of low cardiac output. Extensive endocardial fibroelastosis was found at autopsy in both these patients. The five survivors were extubated 2 to 6 days after the operation (median 3 days). Three patients (patients 3, 4, and 5) showed rapid improvement and were free of symptoms within 1 month. The condition of one deteriorated after 2 months, however. The major problem was left lung atelectasis, and chronic infection necessitated left pneumonectomy. The left ventricular mass continued to increase (in the absence of any residual stenosis), suggestive of a primary myocardial disorder and secondary pulmonary hypertension. The 


\begin{tabular}{ccclcc}
\hline $\begin{array}{c}\text { Repeated } \\
\text { palliation }\end{array}$ & $\begin{array}{c}\text { Age at repeated } \\
\text { palliation (days) }\end{array}$ & $\begin{array}{c}\text { Ventillatory } \\
\text { support (days) }\end{array}$ & Indication for Ross procedure & $\begin{array}{c}\text { Ao/Pa by } \\
\text { echo (mm) }\end{array}$ & $\begin{array}{c}\text { Age at Ross } \\
\text { operation (wk) }\end{array}$ \\
\hline Transventricular & 15 & 53 & CHF, MR & $6 / 11$ \\
Open valvotomy & 8 & $52(2)^{*}$ & CHF, residual stenosis, AR & 5 \\
NA & NA & NA & CHF, residual stenosis & $5 / 13.5$ & 7 \\
Balloon dilation & 66 & $36(2)$ & CHF, residual stenosis, angina pectoris (?) & $6.5 / 12.5$ & 4 \\
NA & NA & $16(3)$ & Avulsion of aortic valve, residual stenosis & $6 / 10$ & 15 \\
NA & NA & $16(2)$ & Avulsion of aortic valve, AR & $6 / 10$ & 6 \\
NA & NA & NA & Small aortic diameter & $5 / 9$ & 5 \\
\hline
\end{tabular}

\begin{tabular}{|c|c|c|c|c|}
\hline \multicolumn{5}{|c|}{ Echocardiographic evaluation during follow-up } \\
\hline Aortic valve & LVOT & Distal anas. & LV function & Other \\
\hline No gradient, trivial AR & Mild gradient $(16 \mathrm{~mm} \mathrm{Hg})$ & Laminar flow & Normal & Trivial MR \\
\hline No gradient & Mild gradient (14 mm Hg) & Laminar flow & Impaired diastolic & EFE, PHT (mod) \\
\hline No gradient, trivial AR & Laminar flow & Laminar flow & Impaired diastolic & HNCM, PHT (sev) \\
\hline No gradient & Laminar flow & Laminar flow & Normal & \\
\hline No gradient & Laminar flow & Laminar flow & Normal & \\
\hline
\end{tabular}

child's condition continued to deteriorate, with death occurring 1 year after the Ross operation.

The condition of two other survivors (patients 1 and 2) improved more slowly. They needed prolonged treatment for congestive heart failure until 2 years of age. Endocardial fibroelastosis was diagnosed by echocardiography before the operation in both of these patients, and this condition probably influenced their slow recovery.

The pulmonary autograft was found to have trivial regurgitation directly after the operation in two of our five survivors, but no signs of progression of this regurgitation were apparent during follow-up. No evidence of stenosis could be detected either at the valvular level or at the distal anastomosis. A mild projection of the ventricular septum into the LVOT was seen in our first two patients, causing a mild gradient of $15 \mathrm{~mm} \mathrm{Hg}$; this gradient has remained unchanged during 3 years of follow-up.

\section{Discussion}

Management of critical aortic stenosis is dependent on the anatomic and functional properties of the left ventricle, the aortic valve, and the mitral valve. A small left ventricle (inlet length $<25 \mathrm{~mm}$ ), narrow aortic valve ring $(<5 \mathrm{~mm})$, and small mitral valve orifice $(<9 \mathrm{~mm})$ make survival after valvotomy or dilation procedures unlikely. ${ }^{3,14}$ In these patients, either the Norwood procedure or cardiac transplantation should be considered. Likewise, if extensive fibroelastosis is present, the left ventricle will not be able to maintain adequate systemic circulation and biventricular repair will fail. $\mathrm{Al}$ though assessment of anatomic dimensions is easy, it may be impossible to differentiate between overwhelming pressure load and endocardial fibroelastosis as the major cause of left ventricular dysfunction before the operation.

In patients with appropriate anatomic dimensions, survival is influenced by how well the left ventricular obstruction is relieved, especially if the aortic or mitral valve is incompetent. ${ }^{14}$

Replacement of the aortic valve would effectively improve the anatomic and functional status of the LVOT. The use of allografts in infants is limited by the problem of rapid outgrowth of the 
conduit, however, as well as by the rapid onset of degenerative changes and dysfunction of these allografts. ${ }^{14}$

On the other hand, the pulmonary autograft has the potential to grow, $3,16,17$ and its durability in adults has been documented. ${ }^{16}$ These were the major reasons for choosing the Ross procedure in our infants, whose clinical status necessitated further interventions and whose anatomic and functional conditions were such that aortic valve replacement appeared to be the treatment of choice.

As mentioned earlier, the presence and extent of endocardial fibroelastosis is also a major determinant of the outcome of patients with critical aortic stenosis. Fibroelastosis may be present in small, contracted cavities, as well as in dilated cavities. ${ }^{13}$ Although thick and generalized endocardial fibroelastosis is expected to cause significant diastolic dysfunction, patchy and localized endocardial fibroelastosis may interfere only mildly with left ventricular performance. Although endocardial fibroelastosis is more common in patients who do not survive surgical treatment, a substantial number of survivors do have echocardiographic evidence of endocardial fibroelastosis, such as endocardial hyperechogenicity. We could not clearly differentiate the severely thickened endocardium found at autopsy in our two nonsurvivors from the endocardial fibroelastosis in those who survived, and echocardiography, at least in our hands, is not sufficiently specific to indicate the severity of the endocardial fibroelastosis.

The performance of the pulmonary autograft during this short-term follow-up is satisfactory, with no signs of deterioration. The trivial aortic regurgitation noted in two of our patients directly after the operation is similar to that seen in patients with transposition in whom the arterial switch operation has been used. Even though the presence of aortic regurgitation raises some concern, no signs of progressive regurgitation have been noted during up to 3 years of follow-up in our series. Further studies are needed, however, to assess the long-term prognosis of the valve. The maintained laminar flow at the distal anastomosis suggests that the diameter increases adequately as the child grows. Inasmuch as the viability of the pulmonary autograft has been verified, ${ }^{15}$ such an appropriate increase in size may represent active growth.

In conclusion, we have found the Ross procedure useful in the management of infants who have critical aortic stenosis suitable for biventricular repair and in whom other palliative measures failed. The complete normalization of the LVOT and competent valve function may compensate for reduced left ventricular function and make the Ross operation preferable to the Norwood type of secondary palliation in this subgroup of critically ill patients.

\section{REFERENCES}

1. Pelech AN, Dyck JD, Trusler GA, et al. Critical aortic stenosis: survival and management. J Thorac Cardiovasc Surg 1987;94:510-7.

2. Hammon JW, Lupinetti FM, Maples MD, et al. Predictors of operative mortality in critical valvular aortic stenosis presenting in infancy. Ann Thorac Surg 1988;45:537-40.

3. Rhodes LA, Colan SD, Perry SB, Jonas RA, Sanders SP. Predictors of survival in neonates with critical aortic stenosis. Circulation 1991;84:2325-35.

4. Mesina LM, Turley K, Stanger P, Hoffman JIE, Ebert PA. Successful aortic valvotomy for severe congenital valvular aortic stenosis in the newborn infant. $J$ Thorac Cardiovasc Surg 1984;88:92-6.

5. Duncan K, Sullivan I, Robinson P, Horvath P, de Leval M, Stark J. Transventricular aortic valvotomy for critical aortic stenosis in infants. J Thorac Cardiovasc Surg 1987;93:546-60.

6. Balaji S, Keeton BR, Sutherland GR, Shore DF, Monro JL. Aortic valvotomy for critical aortic stenosis in neonates and infants aged less than one year. Br Heart J 1989;61:358-60.

7. Zeevi B, Keane JF, Castaneda AR, Perry SB, Lock JE. Neonatal critical valvar aortic stenosis: a comparison of surgical and balloon dilation therapy. Circulation 1989;80: 831-9.

8. Ross DN. Replacement of the aortic and mitral valve with a pulmonary autograft. Lancet 1967;2:956-8.

9. Gerosa G, McKay R, Davies J, Ross DN. Comparison of the aortic homograft and the pulmonary autograft for the aortic valve or root replacement in children. $\mathbf{J}$ Thorac Cardiovasc Surg 1991;102:51-61.

10. Elkins RC, Santangelo K, Randolph JD, et al. Pulmonary autograft replacement in children: The ideal solution? Ann Surg 1992;216:363-70.

11. Schoof $\mathrm{PH}$, Cromme-Dijkhuis $\mathrm{AH}$, Bogers AJJC, et al. Aortic root replacement with pulmonary autograft in children. J Thorac Cardiovasc Surg 1994;107:367-73.

12. Kouchoukos NT, Davilla-Roman VG, Spray TL, Murphy SF, Perillo JB. Replacement of the aortic root with a pulmonary autograft in children and young adults with aortic valve disease. N Engl J Med 1994;330:1-6.

13. Morrow AG. Hypertrophic subaortic stenosis: operative methods to relieve left ventricular outflow obstruction. J Thorac Cardiovasc Surg 1978;76:423-30.

14. Leung MP, McKay R, Smith A, Anderson RH, Arnold R. Critical aortic stenosis in early infancy: anatomic and echocardiographic substrates of successful open valvotomy. J Thorac Cardiovasc Surg 1991;101:526-35.

15. Clarke R. Extended aortic root replacement with cryopreserved allografts; Do they hold up? Ann Thorac Surg 1991; 52:669-75.

16. Ross D, Jackson M, Davies J. The pulmonary autograft-a permanent aortic valve. Eur J Cardiothorac Surg.1992;6: $113-6$.

17. Bourlon F, Quaegebeur J, Lecompte Y, Dor V. Ross procedure in children. Cardiol Young 1995;5(Suppl 1):S11. 